\title{
INHIBITION OF ZONA SHEDDING OF RABBIT BLASTOCYSTS IN CULTURE BY THE PRESENCE OF A MUCIN COAT
}

\author{
MICHAEL T. KANE \\ Department of Physiology, University College, Cork, Ireland
}

(Received 13th November 1974)

\begin{abstract}
Summary. Rabbit ova, with and without mucin coats, were cultured to the expanding blastocyst stage. The presence of a mucin coat appeared to inhibit shedding of the zona pellucida by the expanding blastocysts.
\end{abstract}

Mammalian ova at the time of ovulation are surrounded by a non-cellular layer, the zona pellucida. This layer has a neutral or weakly acid mucopolysaccharide composition (Braden, 1952). Mouse blastocysts have been observed to shed or 'hatch' from the zona in utero (Bergström, 1972) and in vitro (Brinster, 1963). There is some evidence that this may occur in utero in other species, e.g. rat (Dickmann, 1969), plains viscacha (Roberts \& Weir, 1973) and sheep (Bindon, 1971). It has also been suggested that uterine enzymes lyse the zona (McLaren, 1969; Wu, 1973).

Rabbit blastocysts in vivo have not been observed to shed the zona. Instead, expansion of the blastocyst stretches the zona to extreme thinness (Boving, 1957). When rabbit blastocysts have been cultured in vitro from the one-cell stage, however, zona shedding has been demonstrated in a manner similar to that of mouse blastocysts. This occurs in a variety of culture media; in a synthetic medium with $1.5 \%$ crystallized bovine serum albumen (Kane, 1972), in a synthetic medium with $20 \%$ rabbit serum (Ogawa et al., 1972) and in oviducal fluid (Kille \& Hammer, 1973). This difference in behaviour in vivo and in vitro is puzzling and has been ascribed to unknown uterine factors by Kille \& Hammer (1973).

An alternative explanation is possible. Rabbit ova, in contrast to those of almost all other mammals, acquire a second covering in the oviduct and uterus called the 'albumen' layer or mucin coat (Boving, 1957; see also Pl. 1, Fig. 2). This layer is almost completely absent from rabbit blastocysts cultured from the one-cell stage (Pl. 1, Fig. 1). It seems possible, therefore, that rabbit blastocysts in vivo might be prevented from hatching by the mucin coat, but in culture without mucin coats they behave like mouse blastocysts and shed the zona as they expand. To test this hypothesis, ova collected at the one-cell stage with little or no mucin coat and at the morula stage with an obvious mucin coat were placed in culture and observed during blastocyst expansion.

Ovum collection procedures were carried out as described previously, with 
minor modifications (Kane \& Foote, 1970). One-cell fertilized ova with mucin layers less than $5 \mu \mathrm{m}$ in thickness were collected from New Zealand does 20 to $21 \mathrm{hr}$ after an ovulatory injection of HCG (Organon); these were classified as 'mucin coat-free' ova. Morulae with mucin layers ranging in thickness from 59 to $112 \mu \mathrm{m}$ were collected from the oviducts $2 \frac{1}{2}$ to 3 days after the HCG injection; these were classified as 'mucin-coated' ova. The range of mucin layer thickness was checked using a microscope eye-piece micrometer. After removal of oviducal debris from the ova by washing with culture medium, the ova were cultured in $0.5 \mathrm{ml}$ drops of medium under liquid paraffin in plastic tissue culture dishes. The dishes were held at $38^{\circ} \mathrm{C}$ in a gas phase of $5 \% \mathrm{CO}_{2}$ in air. The culture medium contained $1.5 \%$ crystallized bovine serum albumen (Sigma), $108 \mathrm{~mm}-\mathrm{NaCl}, 4 \cdot 78 \mathrm{~mm}-\mathrm{KCl}, 1 \cdot 71 \mathrm{~mm}-\mathrm{CaCl}_{2} \cdot 2 \mathrm{H}_{2} \mathrm{O}, 1 \cdot 19 \mathrm{~mm}-\mathrm{KH}_{2} \mathrm{PO}_{4}, 1 \cdot 19$ mu- $\mathrm{MgSO}_{4}, 25 \mathrm{~mm}-\mathrm{NaHCO}_{3}, 100 \mathrm{U}$ penicillin $\mathrm{G}$ and $50 \mu \mathrm{g}$ streptomycin sulphate per $\mathrm{ml}$. This was supplemented with the amino acids, trace elements and vitamins of Ham's F10 medium (Ham, 1963).

Table 1. Zona shedding in 'mucin coat-free' and 'mucin-coated' rabbit blastocysts in culture

\begin{tabular}{lcccc}
\hline & $\begin{array}{c}\text { Thickness of } \\
\text { mucin layer }(\mu \mathrm{m})\end{array}$ & $\begin{array}{c}\text { No. of } \\
\text { ova }\end{array}$ & $\begin{array}{c}\text { No. of } \\
\text { expanded } \\
\text { blastocysts }\end{array}$ & $\begin{array}{c}\% \text { Blastocysts } \\
\text { shedding the } \\
\text { zona }\end{array}$ \\
\hline $\begin{array}{l}\text { 'Mucin coat-free' ova* } \\
\text { 'Mucin-coated' ovat }\end{array}$ & $0-5$ & 94 & 49 & 95 \\
& $59-112$ & 60 & 47 & 36 \\
\hline
\end{tabular}

* Ova collected at the one-cell stage about $20 \mathrm{hr}$ after HCG and cultured for 5 days. $\uparrow$ Ova collected as morulae $2 \frac{1}{2}$ to 3 days after HCG and cultured for 3 days.

The 'mucin coat-free' one-cell ova were cultured for 5 days and the 'mucincoated' morulae for about 3 days. Thus, all embryos were aged about 6 days (dated from the time of HCG injection) at the end of culture. Ova were examined microscopically twice daily during the period of blastocyst formation. More frequent examination was not carried out for fear of damaging the ova. Numbers of blastocysts shedding the zona were recorded and blastocyst diameters were measured to discover at what stage shedding occurred. In the case of the 'mucin coat-free' blastocysts, it was possible to observe the shedding process and to measure blastocyst diameter during it. In the case of the 'mucin-coated' blastocysts which shed the zona, the process occurred very rapidly and was not usually observed with twice daily examination of ova. Blastocyst diameter was, therefore, measured at the first examination after shedding. The diameters of 'mucin-coated' blastocysts which did not shed the zona were measured at the end of the culture period.

A very high proportion of 'mucin coat-free' expanding blastocysts shed the zona (Table 1). The mean blastocyst diameter at which zona shedding was observed in the 'mucin coat-free' ova (188 $\pm 8 \mu \mathrm{m}, 47$ ova) was only slightly greater than the ovum diameter (130 to $140 \mu \mathrm{m}, \mathrm{Pl}$. 1, Fig. 1) before blastocyst expansion occurred. This fact and the appearance shown in Pl. 1, Fig. 3 indicate that escape from the zona began almost as soon as blastocyst expansion 


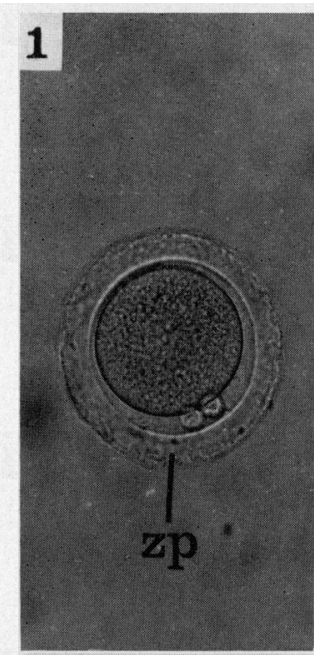

4

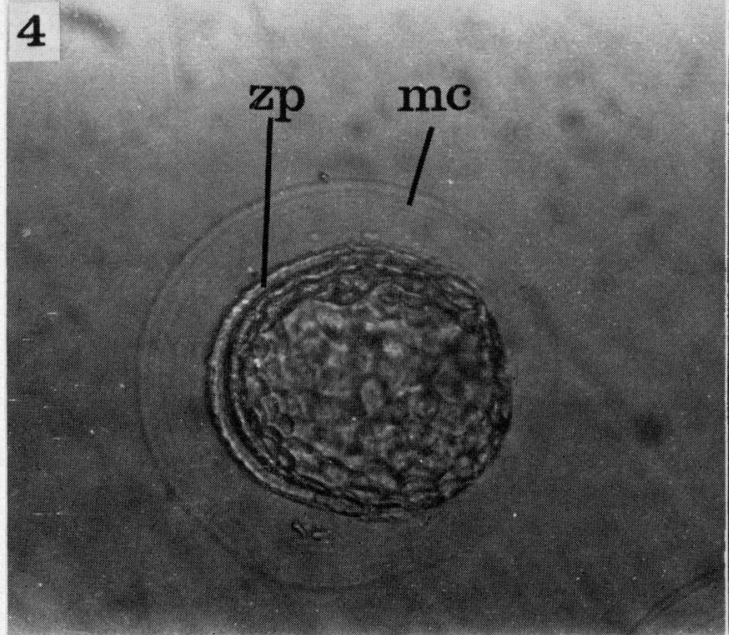

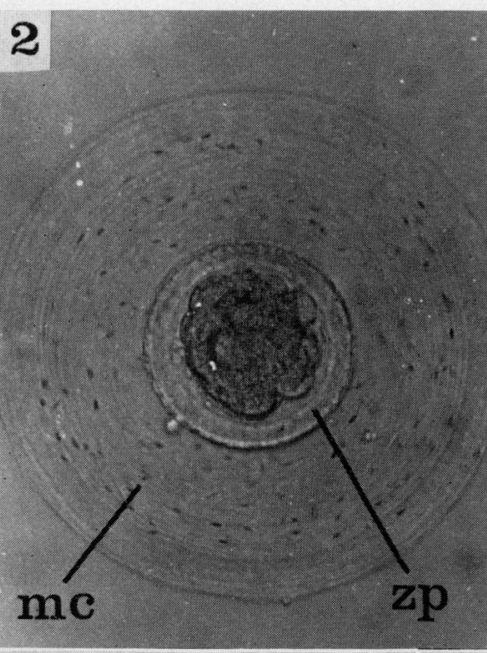
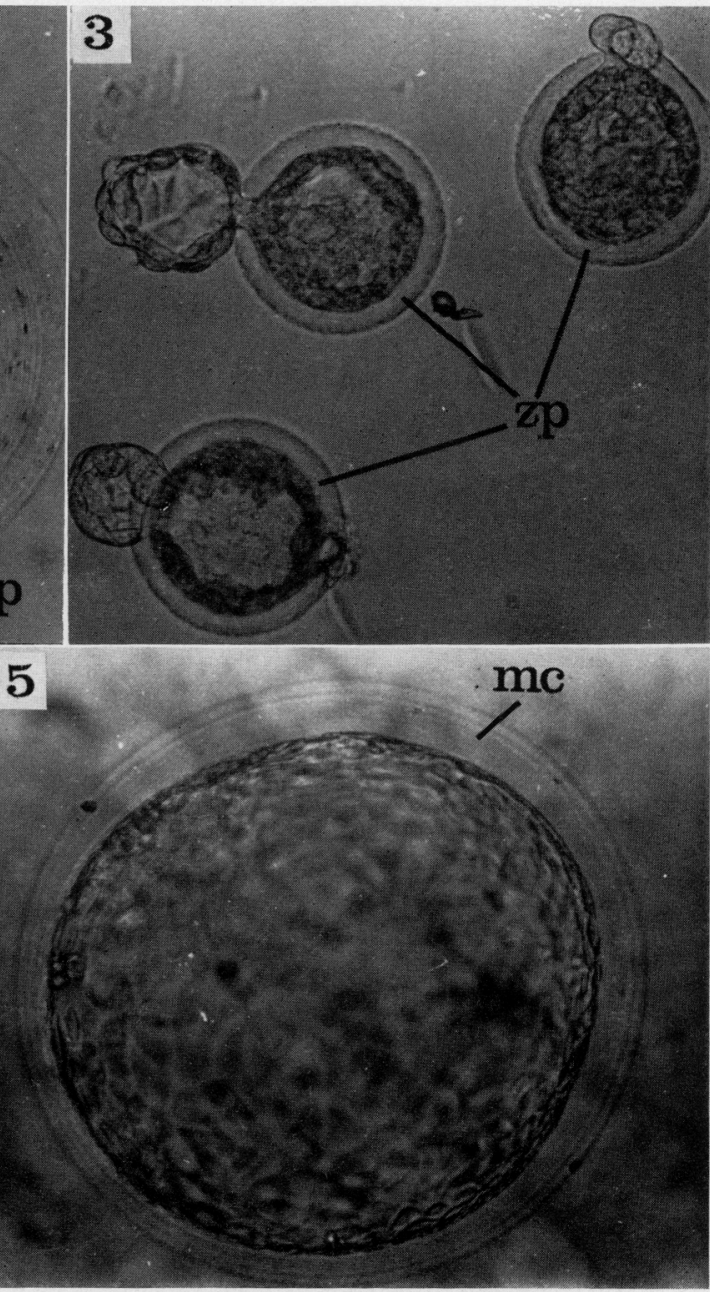

Rabbit ova belore and during culure. Ml ovawere photographed directly from the culture dish using normal light optics and without staining. Magnification about $\times 120$ in all cases. zp. Zona pellucida; me, mucin coat.

Fis. 1. One-cell ovum collected about $20 \mathrm{hr}$ after HCG. Note the almost complete absence of a mucin coat.

Fic. 2. Morula collected 2! days after HCC: There is a thick mucin coat surrounding the zona pellucida.

Fis. 3. 'Three "mucin coat-frec' blastocysts cultured from one-cell ova at different stages of zona shedding. About 3 days after the start of culture, i.e. 4 days after HCG .

Fic. 4. Expanding 'mucin-coated' blastocyst cultured from the morula stage. The zona pellucida is thinned due to blastocyst expansion. This thinning is very marked at one particular area. About 1 day in culture, i.e. 4 days after HCG.

Fic. 5. Expanded 'mucin-coated' blastocyst cultured from the morula stage. Blastocyst expansion has resulted in thinning of the zona to such an extent that it is almost completely invisible. About 2 days in culture i.e. 5 days after HCC.

Facing p. 340 
commenced. Blastocyst escape always occurred through a small slit in the zona (Pl. 1, Fig. 3). The few 'mucin coat-free' blastocysts which did not shed the zona in these experiments degenerated after very limited growth. The 30 $(64 \%)$ 'mucin-coated' blastocysts which did not shed the zona had a mean blastocyst diameter of $619 \pm 38 \mu \mathrm{m}$ at the end of culture; a few blastocysts grew to diameters of over $1000 \mu \mathrm{m}$ without shedding the zona. The 'mucin-coated' blastocysts (seventeen) which shed the zona did so only after a very marked degree of blastocyst expansion, as shown by the figure of $598 \pm 43 \mu \mathrm{m}$ for the mean blastocyst diameter just after zona shedding.

Microscopic examination showed that as 'mucin-coated' blastocysts expanded, the zona was stretched and became progressively thinner (Pl. 1, Fig. 4). This thinning of the zona was often most marked in one particular area, possibly due to weakening or lysis of the zona by the blastocyst at this point. Such pronounced unevenness in the thickness of zonae around blastocysts expanding in vivo has not been observed but less marked unevenness has been seen (M. T. Kane, unpublished observations). Blastocysts did not usually escape through this weakened area. This may have been due to a containing influence of the mucin coat. As blastocyst expansion continued, thinning of the whole zona became so pronounced (Pl. 1, Fig. 5) that the zona was usually not visible at the maximum magnification used for ovum examination $(\times 200)$. When zona shedding did occur, it did not do so until the mucin coat itself was thinned out by blastocyst expansion. Examination of the shed zona-mucin coat complexes indicated that much of the zona had often disappeared, possibly due to lysis of the zona by the blastocyst.

These data strongly suggest that the mucin coat of rabbit ova prevents zona shedding in vitro, and also possibly in vivo. It could be argued that the failure of 'mucin-coated' compared with 'mucin coat-free' blastocysts to shed their zonae was due to the longer time spent in the oviduct by the 'mucin-coated' ova. Definitive evidence on this would be provided by the deposition of an artificial mucin coat on ova in culture, but efforts in this laboratory at depositing such a coat with commercial preparations of mucin have so far failed.

It is interesting to relate these studies to electron microscopic studies on advanced stages of the rabbit blastocyst developed in vivo. Larsen (1961) found that the zona pellucida was absent after the 6 th day of pregnancy, i.e. about 1 day before the start of implantation. A more recent study by Steer (1970) refers to the zona pellucida at 7 days of pregnancy. This is an error since the structure shown as the zona is over $10 \mu \mathrm{m}$ thick in places and must therefore be the mucin coat. The original thickness of the zona is about $15 \mu \mathrm{m}$ and the 50 -fold expansion of the blastocyst taking place before implantation causes extreme thinning of the zona (Boving, 1957). According to Boving, the confusion of mucin coat for zona pellucida in the rabbit is quite common. Examination of Steer's micrographs shows there is no other non-cellular layer present under the mucin coat, suggesting that the zona has not just been thinned but may have been digested away during blastocyst expansion. Support for this idea is provided by the work of Enders (1971) who found that thinning of the rabbit zona during blastocyst expansion was very irregular. The zona became very thin over projecting portions of trophoblast cells and by the 6 th day had been penetrated in many 
places. By the time of implantation it could not be distinguished as a separate layer (Enders, 1971). These studies on blastocysts developed in vivo suggest that digestion of the zona may take place during rabbit blastocyst expansion in utero.

This work was supported by a grant from the Medical Research Council of Ireland.

\section{REFERENCES}

Bergström, S. (1972) Shedding of the zona pellucida of the mouse blastocyst in normal pregnancy. F. Reprod. Fert. 31, 275-277.

BrNDon, B.M. (1971) Systematic study of preimplantation stages of pregnancy in sheep. Aust. F. biol. Sci. 24, 131-147.

Braden, A.W.H. (1952) Properties of the membranes of rat and rabbit eggs. Aust. F. sci. Res., Ser. B, 5, $460-471$.

Brinster, R.L. (1963) A method for the in vitro cultivation of mouse ova from two-cell to blastocyst. Expl Cell Res. 32, 205-208.

Boving, B.G. (1957) Rabbit egg coverings. Anat. Rec. 127, 270.

Dickmann, Z. (1969) Shedding of the zona pellucida. Adv. Reprod. Physiol. 4, 187-206.

ENDERs, A.C. (1971) The fine structure of the blastocyst. In The Biology of the Blastocyst, pp. 71-94. Ed. R. J. Blandau. The University of Chicago Press, Chicago.

HAM, R.G. (1963) An improved nutrient solution for diploid Chinese hamster and human cell lines. Expl Cell Res. 29, 515-526.

KANE, M.T. (1972) Energy substrates and culture of single cell rabbit ova to blastocysts. Nature, Lond. 238, 468-469.

KANe, M.T. \& Foote, R.H. (1970) Culture of two- and four-cell rabbit embryos to the expanding blastocyst stage in synthetic media. Proc. Soc. exp. Biol. Med. 133, 921-925.

Kille, J.W. \& HAMmER, C.E. (1973) The influence of oviducal fluid on the development of one-cell rabbit embryos in vitro. F. Reprod. Fert. 35, 415-423.

LARSEN, J.F. (1961) Electron microscopy of the implantation site in the rabbit. Am. F. Anat. 109, 319334.

McLaren, A. (1969) A note on the mouse zona pellucida. Adv. Reprod. Physiol. 4, 207-210.

Ogawa, S., Satoh, K., Hamada, M., \& Hashimoto, H. (1972) In vitro culture of rabbit ova fertilized by epididymal sperms in chemically defined media. Nature, Lond. 238, 270-271.

RoBerts, G.M. \& WEIR, B.J. (1973) Implantation in the plains viscacha, Lagostomus maximus. F. Reprod. Fert. 33, 299-307.

STEER, H.W. (1970) The trophoblastic knobs of the preimplanted rabbit blastocyst: a light and electron microscope study. F. Anat. 107, 315-325.

Wu, J.T. (1973) Precocious shedding of the zona pellucida in rats treated with progesterone. 7 . Reprod. Fert. 33, 331-335. 